\title{
Parenting System Towards Feeding the Children of Elementary Students at Binaus Village
}

\section{Pola Asuh Orang Tua Terhadap Pemberian Makan Pada Anak Usia Sekolah Dasar di Desa Binaus}

\author{
Priska V.G. Suratman *, R.L.N.K. Retno Triandhini, Arwyn W. Nusawakan
}

\section{Abstract}

Elementary school children are one of the group that can easily get malnutrition because of some factors such as low economic level of the family, unbalanced food nutrition, and lack of knowledge of the parents. A good nutrition status of children is affected by parenting system because children need supervision from the parents for their nutrition needs. Parenting system is a form of interaction in which the parents pay their attention on their children's needs especially for the children's growth process. The purpose of this research is to find out which parenting systems that are applied toward feeding their elementary school children at Binaus Village. This research used quantitative descriptive method with the total participants were 117 parents of 146 children. Questionnaire was used to collect the data. Data analysis used was univariat and the result showed that the majority of mother at Binaus Village, district of Mollo Tengah (Central Mollo), Timor tengah Selatan, East Nusa Tenggara Province, applied authoritative parenting system (79,5\%). Although the parents have less amount of income and lack of educational background, the application of authoritative parenting system at Binaus Village is high.

Keywords: Parenting system, education, income

\section{Intisari}

Anak-anak sekolah dasar merupakan salah satu kelompok yang rawan mengalami gizi kurang penyebabnya adalah tingkat ekonomi yang rendah, asupan makanan yang kurang seimbang dan rendahnya pengetahuan orang tua. Status gizi yang baik pada anak juga dipengaruhi oleh pola pengasuhan orang tua karena anak butuh pengawasan untuk kebutuhannya. Pola pengasuhan merupakan suatu bentuk interaksi yang mana orang tua memperhatikan segala kebutuhan anak dan yang paling penting adalah untuk tumbuh kembangnya. Tujuan penelitian yaitu untuk mengetahui pola pengasuhan orang tua terhadap pemberian makan pada anak usia sekolah dasar di Desa Binaus. Metode yang digunakan yaitu kuantitatif deskriptif dengan populasi sebanyak 117 orang tua (ibu) dari 146 orang anak. Data diperoleh dengan menggunakan kuesioner. Analisa data yang digunakan yaitu univariat dan didapatkan hasil mayoritas orang tua (ibu) di Desa Binaus, Kecamatan Mollo Tengah, Kab. Timor Tengah

Afiliasi Penulis

Universitas Kristen Satya Wacana

Korespondensi kepada

P.V.G. Suratman

priskasuratman@gmail.com
Selatan, NTT menggunakan pola asuh otoritatif $(79,5 \%)$. Dengan penghasilan dan pendidikan yang rendah, penerapan pola asuh otoritatif di Desa Binaus cukup tinggi.

Kata kunci: Pola asuh, pendidikan, penghasilan 


\section{Pendahuluan}

Anak usia sekolah dasar adalah anak yang berumur 6-12 tahun dan pada masa ini anak masih mengalami tumbuh kembang. Tahap perkembangan menurut Freud untuk anak usia sekolah yaitu tahap laten (6-12 tahun) di mana anak mulai berhadapan dengan tuntutan sosial seperti memulai sebuah hubungan dalam kelompok teman sebaya. Anak juga mulai menggunakan energi untuk melakukan aktivitas fisik dan intelektual bersama kelompok sosial dan dengan teman sebayanya. ${ }^{10,27}$ Anak akan banyak berada di luar rumah untuk jangka waktu antara 4-5 jam. Aktivitas fisik anak semakin meningkat seperti pergi dan pulang sekolah, bermain dengan teman, akan meningkatkan kebutuhan energi. Apabila anak tidak memperoleh energi sesuai kebutuhannya maka akan terjadi pengambilan cadangan lemak untuk memenuhi kebutuhan energi, sehingga anak menjadi lebih kurus dari sebelumnya. ${ }^{12}$ Untuk itu, energi yang dibutuhkan anak-anak didapat dari sebuah proses yang dinamakan glikolisis. Proses ini berfungsi untuk mengubah glukosa menjadi piruvat dan akan menghasilkan ATP tanpa menggunakan oksigen.

Glikolisis dimulai dengan satu molekul glukosa yang memiliki 6 atom karbon pada rantainya $\left(\mathrm{C}_{6} \mathrm{H}_{12} \mathrm{O}_{6}\right)$ dan akan dipecahkan menjadi dua molekul piruvat yang masing-masing memiliki 3 atom karbon $\left(\mathrm{C}_{3} \mathrm{H}_{4} \mathrm{O}_{3}\right)$ yang merupakan hasil akhir bagi proses ini. ${ }^{13}$ Sepanjang proses glikolisis ini akan terbentuk beberapa senyawa, seperti Glukosa 6-fosfat, Fruktosa 6-fosfat, Fruktosa 1,6-bisfosfat, Dihidroksi aseton fosfat, Gliseraldehid 3-fosfat, 1,3Bisfosfogliserat, 3-Fosfogliserat, 2-Fosfogliserat, Fosfoenol piruvat dan piruvat. Selain itu, proses glikolisis ini juga akan menghasilkan molekul ATP dan NADH (di mana 1 NADH menghasilkan 3 ATP). Sejumlah 4 molekul ATP dan 2 molekul NADH (6 molekul ATP) akan dihasilkan dan pada tahap awal proses ini memerlukan 2 molekul ATP. Sebagai hasil akhir, 8 molekul ATP akan terbentuk. ${ }^{1}$

Setiap aktivitas fisik memerlukan energi, sehingga jika mengalami kekurangan energi dan protein menurut Almatsier pada anak-anak akan menyebabkan terhambatnya pertumbuhan, rentan terhadap penyakit terutama penyakit infeksi, dan mengakibatkan rendahnya tingkat kecerdasan. ${ }^{2}$

Aktivitas fisik yang dilakukan anak seperti yang telah disebutkan diatas, memerlukan nutrisi yang tepat dan seimbang terutama energi dan protein. Angka kecukupan energi untuk anak umur 7-9 tahun sebanyak $1.850 \mathrm{Kkal}$ dan protein $49 \mathrm{~g}$, pada usia 10-12 tahun (laki-laki) energi sebanyak 2.100 Kkal dan protein $56 \mathrm{~g}$, pada usia 10-12 tahun (perempuan) energi sebanyak $2000 \mathrm{Kkal}$ dan protein $60 \mathrm{~g} .{ }^{15}$

Berdasarkan Survei Diet Total tahun 2014, sebagian besar penduduk di Indonesia memiliki tingkat kecukupan energi sangat kurang dan kurang yaitu sebesar $79,6 \%$. Tingkat kecukupan energi sangat kurang dan kurang tertinggi terjadi di Lampung (89,5\%) dan Nusa Tenggara Timur (89,3\%). Tingkat kecukupan protein sangat kurang dan kurang tertinggi terjadi di Papua $76,2 \%$ dan NTT 73,6\%. ${ }^{18}$ Dari data tersebut dapat disimpulkan bahwa NTT masih memiliki penduduk yang mengalami kekurangan energi dan protein.

Terjadinya kekurangan gizi dan gizi buruk juga bisa disebabkan oleh kemiskinan diantaranya keadaan ekonomi keluarga dan juga ketahanan pangan keluarga. NTT termasuk provinsi yang memiliki penduduk miskin terbesar dengan urutan ke 3 setelah Papua dan Papua Barat. ${ }^{18}$ Keadaan ekonomi dan ketahanan pangan dalam keluarga sangat berpengaruh pada kecukupan gizi terutama energi dan protein. Penelitian yang dilakukan oleh Sebataraja dkk di Kota Padang mengatakan status gizi anak secara tidak langsung berkaitan dengan faktor sosial ekonomi keluarga. Jika status sosial ekonomi rendah maka kebutuhan makanan keluarga akan kurang terpenuhi sehingga anak akan memiliki status gizi kurang. Dalam penelitian tersebut juga didapatkan ada hubungan yang nyata antara status ekonomi keluarga terhadap status gizi anak. ${ }^{22}$

Status gizi yang baik pada anak juga dipengaruhi oleh pola pengasuhan orang tua karena anak butuh pengawasan untuk kebutuhannya yaitu makanan yang dikonsumsi. Menurut Baumrind (dalam Herlambang, 2013) pola asuh terbagi menjadi tiga yaitu otoritatif (demokrasi), permisif, dan otoriter. ${ }^{9}$ Pola asuh otoritatif (demokrasi) adalah pola asuh yang ditandai dengan adanya sikap terbuka antara 
orang tua dan anak, sikap menerima, responsive, berorientasi pada kebutuhan anak yang disertai tuntutan, kontrol dan pembatasan. Pola asuh permisif adalah pola asuh yang ditandai dengan adanya kebebasan tanpa batas dari orang tua terhadap anak untuk berbuat dan berperilaku sesuai keinginan anak. Pola asuh otoriter adalah pola asuh yang ditandai dengan orang tua yang melarang anaknya dengan mengorbankan otonomi anak, bersikap memaksa dengan selalu menuntut kepatuhan anak agar bertingkah laku seperti yang orang tua kehendaki. ${ }^{6}$

Pola asuh sendiri terdiri dari dua kata yaitu pola dan asuh. Menurut Kamus Besar Bahasa Indonesia, pola berarti corak, model, sistem, cara kerja, bentuk (struktur) yang tetap sedangkan asuh berarti menjaga (merawat dan mendidik) anak kecil, membimbing (membantu; melatih dsb), dan memimpin (mengepalai dan menyelenggarakan) satu badan atau lembaga. ${ }^{3}$ Pengasuhan menurut Shochib (2010) adalah orang yang melaksanakan tugas membimbing, memimpin, atau mengelola. Sedangkan mengasuh menurut Darajat (dalam Shochib, 2010) adalah mendidik dan memelihara anak itu, mengurus makan, minum, pakaiannya, dan keberhasilannya dalam periode yang pertama sampai dewasa. ${ }^{23}$ Jadi dari pernyataan tersebut dapat dikatakan bahwa pola pengasuhan orang tua merupakan suatu bentuk tindakan dan interaksi terhadap anak. Orang tua mengasuh, mendidik dan memperhatikan segala kebutuhan yang anak perlukan dan yang paling penting untuk pertumbuhan dan perkembangannya yaitu makanan yang bergizi seimbang. Penelitian yang dilakukan oleh Fatimah di Jombang mengatakan pola asuh orang tua tentang tumbuh kembang sangat membantu anak mencapai dan melewati tumbuh kembang sesuai tingkatan usianya dengan normal. ${ }^{7}$ Jadi dari penelitian tersebut dapat dikatakan bahwa pola asuh orang tua dalam hal ini seorang ibu sangat penting dan berpengaruh untuk tumbuh kembang anak.

Kabupaten TTS (Timor Tengah Selatan) merupakan salah satu kabupaten di NTT yang masih banyak memiliki kasus balita mengalami gizi kurang. Berdasarkan data dari Dinas Kesehatan tentang status gizi balita di Kabupaten TTS tahun 2015 , balita yang mengalami gizi buruk sebanyak
592 orang, gizi kurang sebanyak 1.926 orang dan gizi baik 29.843 orang. ${ }^{17}$ Data tersebut menunjukkan bahwa kecukupan gizi balita di Kabupaten TTS rendah.

Dengan keadaan seperti diatas, maka peneliti ingin melihat dan mencari tahu gambaran pola asuh orang tua terkait pemberian makan terhadap anak usia sekolah dasar di Desa Binaus, Kabupaten TTS, NTT.

\section{Metode}

Penelitian ini menggunakan metode kuantitatif yang bersifat deskriptif dengan tujuan untuk mengetahui pola pengasuhan orang tua dengan menggunakan kuisioner. Instrument yang digunakan dalam penelitian ini yaitu kuisioner The Parenting Styles and Dimensions Questionnaire (PSDQ) berdasarkan teori Baumrind yang dikembangkan oleh Clyde C. Robinson, dkk yang terdiri dari 13 pertanyaan otoritatif, 13 pertanyaan otoriter, dan 4 pertanyaan permisif. ${ }^{19}$ Setelah melakukan uji validitas pada 30 pertanyaan, didapatkan hasil 24 pertanyaan yang valid yaitu 9 pertanyaan otoritatif, 12 pertanyaan otoriter, dan 3 pertanyaan permisif sedangkan uji reabilitas didapatkan dari hasil nilai Alpha Cronbach 0,888. Pertanyaan kuesioner memiliki 5 item pilihan yaitu tidak pernah, kadang-kadang, sering, sangat sering, dan selalu. Untuk menghitung jumlah persentasenya dibagi menjadi 2 yaitu tidak pernah dan selalu.

Populasi dalam penelitian ini adalah 117 orang tua (ibu) dari 146 orang anak usia sekolah dasar berumur 6-12 tahun. Sampel menggunakan teknik total sampling karena peneliti menggunakan semua anggota populasi. Total sampling atau disebut juga sampel jenuh yaitu teknik penentuan sampel dengan cara mengambil seluruh anggota populasi sebagai responden atau sampel. ${ }^{25}$ Kriteria inklusi dalam penelitian ini yaitu orang tua (ibu) yang mengasuh anak tersebut di Desa Binaus. Kriteria eksklusi yaitu partisipan yang tidak dapat digunakan untuk penelitian ini.

Pola asuh dikumpulkan melalui pengisian kuisioner yang dilakukan terhadap orang tua anak. Pengumpulan data tersebut dilakukan di Desa Binaus, Kecamatan Mollo Tengah, Kabupaten Timor Tengah Selatan, NTT pada bulan Juni-Juli 
2017. Teknik analisa data yang digunakan yaitu analisis univariat. Analisis univariat untuk mendeskripsikan bagaimana pola asuh orang tua terhadap anak dalam hal pemberian makan dengan menggunakan SPSS.

\section{Hasil \& Pembahasan}

Berdasarkan hasil penelitian yang sudah dilakukan, orang tua (ibu) yang selalu menggunakan pola asuh otoritatif sebanyak $79,5 \%$, pola asuh otoriter sebanyak $40,4 \%$, dan pola asuh permisif sebanyak $28,8 \%$ (tabel 1). Hal ini menunjukkan bahwa mayoritas orang tua (ibu) di Desa Binaus, Kecamatan Mollo Tengah, Kab. TTS, $\mathrm{NTT}$, menggunakan pola asuh otoritatif. Pola asuh otoritatif sendiri menurut Baumrind (dalam Santrock, 2007:167) merupakan pola asuh yang paling tepat karena orang tua mendorong anak untuk mandiri namun masih menerapkan batasan pada tindakan anak. Anak-anak dengan keluarga otoritatif memiliki kepercayaan diri, harga diri yang tinggi dan menunjuk perilaku yang terpuji. ${ }^{20}$ Orang tua dengan pola asuh otoritatif menetapkan ekspektasi yang jelas dan standar yang tinggi serta memonitoring perilaku anak-anak, menggunakan disiplin penalaran. Mereka juga mendorong anakanak untuk mengambil keputusan dan belajar dari pengalaman mereka. ${ }^{8}$

Sesuai dengan penjelasan diatas, orang tua yang menggunakan pola asuh otoritatif ini mendorong anak untuk bisa mandiri namun dalam batasan tertentu. Hal ini dapat dilihat pada anakanak di Desa Binaus, mereka sudah bisa mandiri dan tidak bergantung pada orang tua. Mandiri dalam hal ini seperti pemberian makan, anak yang sudah berusia 8 tahun ke atas tidak lagi menunggu orang tua untuk terus menyuapi mereka. Mereka sudah bisa mengambil makanan mereka sendiri. Jika orang tua mereka tidak ada, mereka tidak lagi harus menunggu orang tua terus mengingatkan mereka untuk makan. Kecuali yang berumur dibawah 8 tahun yang masih memerlukan pengawasan lebih dari orang tua dalam hal pemberian makan. Ini sesuai dengan hasil penelitian yang dilakukan oleh Dewi (2008) yang menunjukkan bahwa tipe pola asuh demokratis merupakan pola asuh terbanyak yang diterapkan oleh orang tua karena mempunyai prinsip mendorong anak untuk mandiri dalam memilih makanan tapi orang tua menetapkan batas dan kontrol. $^{4}$ Tipe pola asuh demokratis memiliki pengertian yang sama dengan pola asuh otoritatif yang mana sama-sama mendorong anak untuk mandiri namun dalam batasan tertentu.

Pola asuh yang diterapkan ibu juga berpengaruh pada tumbuh kembang anak melalui nutrisi yang diberikan. Bisa dilihat dari penelitian yang dilakukan oleh Munawaroh yang mengatakan pola asuh pemberian makan oleh orang tua mempunyai hubungan yang signifikan terhadap status gizi balita. Semakin baik pola asuh yang diberikan maka semakin baik status gizi balita dan sebaliknya apabila ibu memberikan pola asuh yang kurang baik dalam pemberian makanan pada balita maka status gizi balita juga akan terganggu. ${ }^{14} \mathrm{Hal}$ ini sesuai dengan pendapat Soekirman (dalam Munawaroh) yang mengatakan pola asuh yang baik dari ibu akan memberikan kontribusi yang besar pada pertumbuhan dan perkembangan balita sehingga akan menurunkan angka kejadian gangguan gizi. ${ }^{24}$

Dalam penelitian yang sejenis, yang dilakukan oleh Pratiwi dkk juga didapatkan hasil terdapat hubungan yang bermakna antara pola asuh makan dengan status gizi balita. ${ }^{16}$ Jadi, peranan ibu sangat penting untuk tumbuh kembang anak melalui pola asuh yang diterapkan dan juga dari nutrisi yang diberikan. Dengan pengawasan yang baik dari ibu dalam hal pemberian makan, status gizi anak juga akan menjadi baik. Sesuai dengan pendapat Engle (dalam Pratiwi dkk) yang mengatakan pemberian

Tabel 1 | Pola asuh orang tua.

\begin{tabular}{clll}
\hline Pola Asuh & Intensitas & Frekuensi & Persen \\
\hline \multirow{4}{*}{ Otoritatif } & Tidak pernah & 30 & 20,5 \\
\cline { 2 - 4 } & Selalu & 116 & 79,5 \\
& Total & 146 & 100 \\
\cline { 2 - 4 } Otoriter & Tidak pernah & 87 & 59,6 \\
& Selalu & 59 & 40,4 \\
& Total & 146 & 100 \\
& Tidak pernah & 104 & 71,2 \\
\hline \multirow{2}{*}{ Persuasif } & Selalu & 42 & 28,8 \\
& Total & 146 & 100 \\
\hline
\end{tabular}


makan yang baik sangat penting untuk asupan nutrisi, tidak hanya dari segi apa yang dimakan anak, tapi sikap ibu juga berperan. Misalnya saja adanya kehadiran ibu untuk mengawasi anak makan. Dengan pemberian makan yang baik maka akan menunjang status gizi anak. ${ }^{5}$

Dalam hal penghasilan, dengan perlakuan pola asuh otoritatif terhadap anak dalam pemberian makan, orang tua dapat menanyakan pada anak untuk memberitahukan makanan apa yang mereka inginkan. Diketahui dari penghasilan orang tua yang rata-rata $<R p .500 .000$, secara tidak langsung hal itu menjelaskan bahwa makanan yang diharapkan dari anak tidak akan sepenuhnya terpenuhi oleh orang tua. Menariknya, persentase penerapan pola asuh otoritatif termasuk tinggi. Hal ini menunjukkan bahwa anak-anak di Desa Binaus, Kab. TTS, NTT, menerima keadaan mereka yang mana makanan yang ada tidak selalu sesuai dengan apa yang mereka inginkan dikarenakan kondisi penghasilan keluarga yang rendah.

Faktor yang mempengaruhi pola asuh yaitu pendidikan, budaya dan lingkungan. ${ }^{21}$ Orang tua yang menerapkan pola asuh bisa dilihat dari latar belakang pendidikannya. Namun sebagian besar orang tua mempelajari cara pengasuhan dari orang tua mereka sendiri, atau mengikuti budaya yang sudah ada. Seperti pendapat Santrock yang mengatakan mayoritas budaya orang tua mempelajari praktik pengasuhan dari orang tua mereka sendiri. Yang secara langsung, orang tua mengalami. Jadi, setelah mempunyai anak orang tua mempraktikan didikannya tersebut. Sebagian praktik tersebut mereka terima, namun sebagian lagi mereka tinggalkan. Sayangnya, ketika metode orang tua diteruskan dari satu generasi ke generasi berikutnya, praktik yang baik maupun yang buruk diteruskan. $^{21}$ Latar belakang pendidikan mempengaruhi pola asuh karena dapat memberikan pengetahuan yang baik pada orang tua agar dapat menerapkan pola asuh yang sesuai untuk anak. Hal ini sesuai dengan pendapat Wong yang berpendapat bahwa latar belakang pendidikan orang tua dapat mempengaruhi pola pikir orang tua kemudian juga berpengaruh pada aspirasi atau harapan orang tua kepada anaknya, semakin tinggi pendidikan orang tua maka dapat menerima segala informasi dari luar terutama cara pengasuhan yang baik. ${ }^{26}$

Namun pendapat tersebut berlawanan dengan penelitian yang ditemukan di Desa Binaus. Orang tua yang berpendidikan rendah tidak selalu memiliki pola pengasuhan yang buruk. Walaupun mereka berpendidikan rendah, mereka sering mengikuti sosialisasi yang diadakan oleh pemerintah mengenai cara mengasuh anak dalam pemberian makan. Hal ini bisa dilihat pada orang tua (ibu) di Desa Binaus, kebanyakan dari mereka hanya berpendidikan terakhir SD dapat menerapkan pola asuh otoritatif dan anak-anak mereka sudah bisa mandiri dalam batasan tertentu. Dapat dilihat berdasarkan hasil penelitian yang sebagian besar pendidikan orang tua (ibu) hanya berpendidikan terakhir SD sebanyak 69 orang (59\%) (gambar 1), pekerjaan orang tua (ibu) sebagian besar hanya sebagai Ibu Rumah Tangga sebanyak 104 orang (89\%) (gambar 2), dan penghasilan keluarga di Desa Binaus sebagian besar berpenghasilan rendah yaitu $<$ Rp. 500.000 sebanyak 92 keluarga (79\%) (gambar 3). Penelitian yang sudah dilakukan berbanding terbalik dengan hasil penelitian yang dilakukan oleh Kharmina yang mengatakan bahwa ada pengaruh positif dan signifikan antara Tingkat Pendidikan orang tua terhadap Pola Asuh, pengaruh positif itu jika Tingkat Pendidikan orang tua semakin baik maka

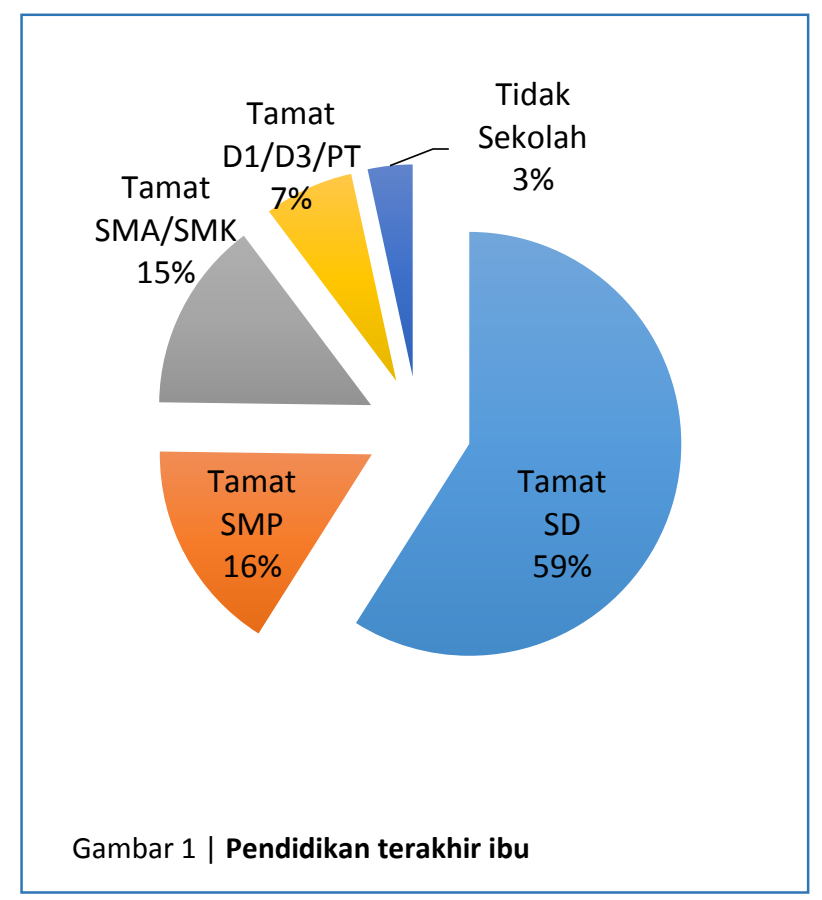




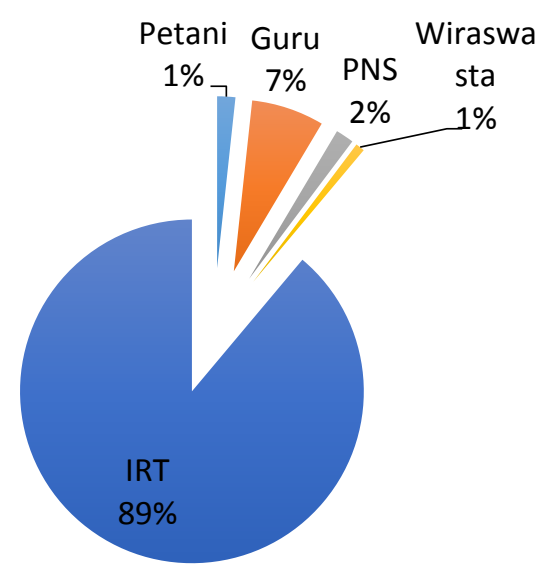

Gambar 2 | Pekerjaan ibu

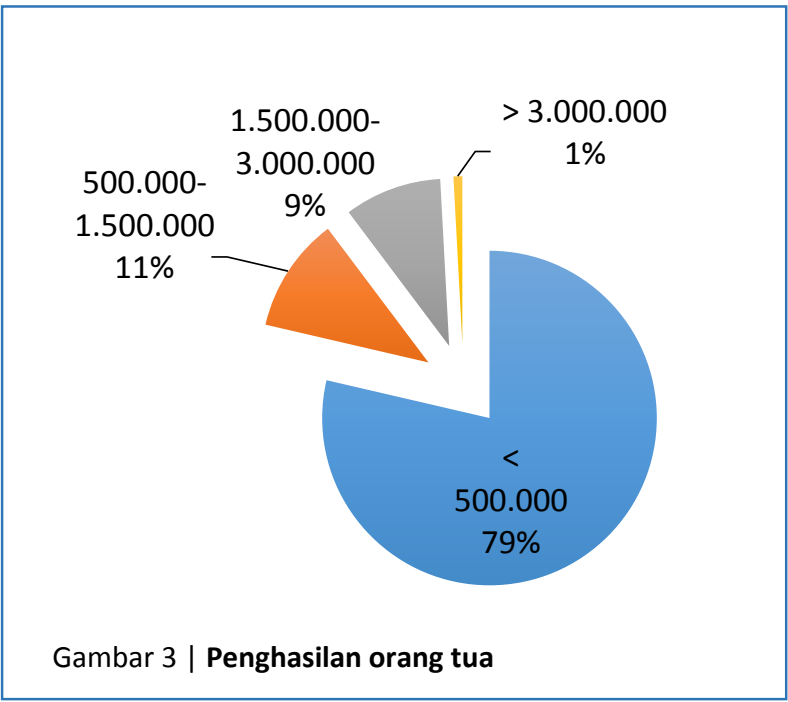

Pola Asuh semakin baik. Sedangkan dari hasil penelitian yang sudah dilakukan, pendidikan orang tua (ibu) yang rendah pun dapat memberikan pola asuh otoritatif yang merupakan pola asuh yang ideal diterapkan pada anak-anak. ${ }^{11}$ Bagi para orang tua hendaknya tetap mempertahankan pola asuh otoritatif yang sudah diterapkan dan untuk peneliti selanjutnya diharapkan dapat meneliti tentang status gizi anak-anak di Desa Binaus dikarenakan masih banyak balita yang menderita gizi buruk maupun gizi kurang yang akan berdampak pada tumbuh kembangnya.

\section{Kesimpulan}

Dari pembahasan diatas dapat disimpulkan bahwa mayoritas orang tua dalam hal ini ibu di Desa Binaus, Kecamatan Mollo Tengah, Kab. TTS, NTT, selalu menggunakan pola asuh otoritatif yaitu
$79,5 \%$. Pola asuh yang diterapkan ibu berpengaruh pada tumbuh kembang anak. Semakin baik pola asuh yang diberikan maka semakin baik status gizi anak dan sebaliknya apabila ibu memberikan pola asuh yang kurang baik dalam pemberian makanan pada anak maka status gizi anak juga akan terganggu.

\section{Bibliografi}

1. Allan D. Marks, Colleen Smith, Michael Lieberman, 2005. Generation of ATP From Glucose: Glycolysis, Marks' Basic Medical Biochemistry. 2nd ed. USA: Williams \& Wilkins: 399-415

2. Almatsier, S. (2006). Prinsip Dasar IImu Gizi. Jakarta: Gramedia Pustaka Utama.

3. Depdikbud. Kamus Besar Bahasa Indonesia. (Jakarta : Balai Pustaka, 1988), h. 54

4. Dewi, I. 2008. Mengenal Bentuk Pola Asuh Orang Tua. viewed 15 September 2008

5. Engle PL, Bentley M, Pelto G.,2010, The Role of Care in Nutrition Programmers: Current Research and a Research Ganda. Proceedings of The Nutrition Society. 59:25-35.

6. Fatimah, L.,2010, Hubungan Persepsi Anak Terhadap Keharmonisan Keluarga dan Pola Asuh Orang Tua Dengan Motivasi Belajar, Tesis. Surakarta: Universitas Sebelas Maret

7. Fatimah, L., 2012, Hubungan Pola Asuh Orang Tua dengan Perkembangan Anak di R.A Darussalam Desa Sumber Mulyo, Jogoroto, Jombang.

8. Greenwood, B., 2013, The Baumrind theory of parenting styles. GlobalPost International News. Retrieved December 15, 2013 from everyday.globalpost.com/baumrind-theory-parentingstyles-6147.html

9. Herlambang ASU, Lilik S, Agustin RW., 2013, Perbedaan Kepercayaan Diri Pada Siswa Dengan Perilaku Bermasalah Ditinjau Dari Pola Asuh Orang Tua di SMAN 1 Kauman Tulungagung. [serial online]. [cited 2014 Oct 24];02(1):1-9.

10. Hockenberry \& Wilson.,2007, Buku Ajar Keperawatan Pediatrik. Jakarta: EGC

11. Kharmina, N., 2011, Hubungan Antara Tingkat Pendidikan Orang Tua Dengan Orientasi Pola Asuh Anak Usia Dini. Semarang.

12. Khomsan, A., 2010, Pangan dan Gizi untuk Kesehatan. Jakarta: Raja Grafindo Persada, 140-143;

13. M. Anwari Irawan, 2007. Glukosa \& Metabolisme Energi, Polton Sports Science \& Performance Lab, Sports Science Brief, No.6, Vol.1, 1-5. 
14. Munawaroh, S., 2015, Pola Asuh Mempengaruhi Status Gizi Balita. Jurnal Keperawatan. 6(1): 44-50

15. Peraturan Menteri Kesehatan Republik Indonesia No. 75., 2013, Angka Kecukupan Gizi yang di Anjurkan Bagi Bangsa Indonesia. Jakarta

16. Pratiwi, T.D dkk., 2016, Hubungan Pola Asuh Ibu dengan Status Gizi Balita di Wilayah Kerja Puskesmas Belimbing Kota Padang. Jurnal Kesehatan Andalas, Vol.3, 661-665

17. Profil Dinas Kesehatan Kabupaten Timor Tengah Selatan. Status Gizi Balita. 2015

18. Profil Kesehatan Indonesia., 2015, Tingkat Kecukupan Energi dan Tingkat Kecukupan Protein. Jakarta

19. Robinson, C., Mandleco, B., Olsen, S. F., \& Hart, C. H., 1995, Authoritative,authoritarian, and permissive parenting practices: Development of a new measure. Psychological Reports, No.77, 819-830.

20. Santrock, J. W., 2007, Perkembangan Anak. Ed. 7 , Jilid 2. Jakarta: Penerbit Erlangga

21. Santrock, John W., 2007, Perkembangan Anak. Jakarta : Erlangga

22. Sebataraja, L.R dkk., 2014, Hubungan Status Gizi dengan Status Sosial Ekonomi Keluarga Murid Sekolah Dasar di Daerah Pusat dan Pinggiran Kota Padang. Jurnal Kesehatan Andalas, No.2, Vol.3, 182187.

23. Shochib, Moh., 2010, Pola Asuh Orang Tua (Dalam Membantu Anak Mengembangkan Disiplin Diri Sebagai Pribadi Yang Berkarakter). Jakarta: Rineka Cipta.

24. Soekirman., 2000, IImu Gizi dan Aplikasinya. Jakarta: Departemen Pendidikan Nasional.

25. Sugiyono., 2013, Metode Penelitian Pendidikan (Pendekatan Kuantitatif, Kualitatif, dan R\&D). Bandung : Alfabeta

26. Wong, D.L, dkk., 2001, Buku Ajar Keperawatan Pediatrik, edisi 6. Jakarta: EGC

27. Wong L.D. Hockenberry M, Wilson D, Winkelsein M.L, \& Schawrtz, P., 2009, Buku Ajar Keperawatan Pediatrik, Vol.2, Ed,6, Jakarta: EGC 